\title{
Post-Entry On-going Organizational Changes in Core Activities of Foreign Subsidiaries and Firm Survival
}

\author{
Kyungho Kim, Ajou University, South Korea
}

\begin{abstract}
By applying conventional organizational adaptation theory, this study explores the relationship between post-entry on-going organizational changes in core areas of foreign subsidiaries, such as investment amount, ownership, and product, and the subsequent survival of such subsidiaries in a host country. This study further investigates the relative importance of subsidiary's organizational change in core areas. For these research questions, this study employs a sample of 2,582 foreign direct investment cases by Korean textile firms. The findings show that a foreign subsidiary's post-entry ongoing organizational changes in the core areas are negatively associated with its mortality rate. However, we carefully qualify this result: ongoing changes in investment amount and product areas help reduce the mortality rate, whereas changes in ownership do not.
\end{abstract}

Keywords: Post-Entry Organizational Change; Foreign Direct Investment; Adaptation; Survival

\section{INTRODUCTION}

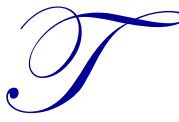

o survive, multinational enterprises (MNEs) entering foreign countries must cope with local and other foreign competitors in a host country and are forced to adapt to a host country's transforming environment through post-entry ongoing organizational changes. Hence, post-entry organizational changes become an urgent strategic issue for foreign investors because they influence subsequent firm performance. This study sets out to explore the fundamental question that has been a main tenet ceaselessly asked about by organizational theorists (Barnett \& Carroll, 1995) but that the international business (IB) literature has relatively little studied: What are the consequences of organizational change?

Organizational change occurs in core dimensions such as mission, authority structure, technology, and marketing strategy (Brown \& Eisenhardt, 1997; Hannan \& Freeman, 1984; Haveman, 1992; Tsoukas, 1996), and in peripheral areas such as changes in specific operational tactics or modifications in programs (March \& Simon, 1958; Singh, House, \& Tucker, 1966). Organizational changes in the core domains are riskier and costlier because they result in a coordination problem and change previous strategies and rules (Barnett \& Freeman, 1997; Greve, 1999; Hannan \& Freeman, 1984) such that existing studies focused on the core areas. However, existing studies did not carefully qualify how a different type of organizational change in the diverse core dimensions influences subsequent performance, and admitted that each area may have a different effect on performance given its unique nature. Accordingly, this study carefully investigates the relationship between post-entry ongoing organizational changes in the different core areas and subsequent performance.

The adaptation perspective has contended that an organization may adapt to a changing environment (Brown \& Eisenhardt, 1997; Pettigrew, Woodman, \& Cameron, 2001). Especially, it has been known that the ongoing adaptive process can increase the chance of organizational survival (Amburgey, Kelly, \& Barnett, 1993; Baum \& Oliver, 1991; Delacroix \& Swaminathan, 1991; Haveman, 1992). According to this argument, this study attempts to examine what kind of organizational changes occur and then what consequences follow.

This study differs from the existing IB research in that it applies a dominant organizational theory in the context of foreign direct investment (FDI) and carefully qualifies how organizational changes in the core areas of a foreign 
subsidiary are related to firm survival at the subsidiary level, given that the adaptation theory is commonly employed to explain population- or firm-level phenomena. Specifically, this study sets out to provide empirical evidence for the consequences of post-entry ongoing organizational changes in the core areas: how different types of post-entry organizational changes in the core areas affect firm performance in a distinct manner. In the next section, we address the theoretical background and develop hypotheses. Next, we present the data and analytical methodology. Finally, after reporting and discussing the findings, we conclude this study by providing its implications and suggesting potential areas for future research.

\section{LITERATURE REVIEW}

\section{Organizational Change and Firm Performance}

Sharma and Erramilli (2004) define FDI as carrying out production and marketing operations in a foreign country by direct investment or with local partners. Although many previous studies have revealed FDI determinants and the relationship between FDI and the resulting economic development (Kok \& Ersoy, 2009; Tsang \& Yip, 2007), Canabal and White III (2008) acknowledged that post-entry ongoing organizational changes would affect firm performance.

Organizational change can be defined as "a transformation of an organization between two points in time" (Barnett \& Carroll, 1995, p. 219). Normally, organizations attempt to implement organizational change for managing a transforming environment so the effect of organizational change on performance can be evaluated by comparing the results before and after organizational change (Greve, 1999; Tsoukas \& Chia, 2002). Organizational change occurs both in core dimensions such as mission, authority structure, technology, and marketing strategy (Brown \& Eisenhardt, 1997; Hannan \& Freeman, 1984; Haveman, 1992; Tsoukas, 1996), and in peripheral areas such as change in specific operational tactics or modifications in programs (March \& Simon, 1958; Singh et al., 1986). Organizational changes in core domains tend to accompany a coordination problem and changes in extant strategies and rules so that these changes are likely to be riskier and lead to disruptive consequences (Barnett \& Freeman, 1997; Greve, 1999). Thus, this study investigates how organizational changes in the core dimensions of foreign subsidiaries are related to foreign subsidiaries' survival.

Two perspectives in organizational theory have established the contrasting arguments about the relationship between organizational changes and subsequent performance. Rather than elaborating their primary arguments, therefore, this study briefly mentions their cores. The selection view emphasizes an excessively static perspective based on organizational structural inertia (Hannan \& Freeman, 1984; Freeman et al., 1983; Singh \& Lumsden, 1990). This perspective argues that organizational changes tend to cause firms to be selected out of the environment (i.e., so-called environmental determinism) because such changes are likely to disrupt the internal rules, routines, and external connections of a firm (Freeman \& Hannan, 1983; Stinchcombe, 1965). Therefore, this perspective assumes that organizations do not attempt to change because such a change is accompanied by significant failure.

The opposite perspective, adaptation view, contends that organizations have more leeway in coping with changing environments (Miles, 1982). This view emphasizes the adaptation process through which organizations attempt to not only adjust to a changing environment but also enact and develop a favorable environment, thus resulting in a desirable outcome (Baum \& Oliver, 1991; Delacroix \& Swaminathan, 1991; Haveman, 1992). An organization that involves evolving individuals pursues organizational changes in order to survive (Barnett \& Burgelman, 1996).

In summary, the challenging question, "What are the consequences of organizational change?" (Barnett \& Carroll, 1995) may be more critical when entering foreign markets because foreign subsidiaries face more fundamental adaptation problems in response to new economic, institutional, and competitive environments. With this in mind, we investigate the relationship between post-entry ongoing organizational changes in the core areas of foreign subsidiaries and their survival in a host country.

\section{Hypotheses: Post-entry Organizational Changes and Mortality Rate}

Organizational changes in the core dimensions have a disruptive effect on firm performance (Hannan \& Freeman, 1984; Singh et al., 1986). For example, in interviews with several chief executive officers (CEOs) of Korean textile 
firms, Kim (2014) found that Korean textile firms have attempted organizational changes of their foreign subsidiaries in core areas such as investment amount (i.e., level of resource commitment), product, and ownership (i.e., level of equity) to adjust to a changing environment in a host country. That is, strategic organizational changes in foreign direct investment amount, ownership, and product areas were fundamental to a post-entry strategy for Korean textile firms' foreign subsidiaries to manage the changing environment in a given foreign market.

Kim (2014) also acknowledged that three Korean government-affiliated organizations (e.g., the Korea EXIM Bank, the Korea Trade-Investment Promotion Agency, and the Ministry of Strategy and Finance) recorded historical data in investment, ownership, and product areas to monitor the operational activities of Korean textile firms in foreign countries. With this in mind, this study assumes that organizational changes in these core activities of foreign subsidiaries may contribute to their survival rate (which is used interchangeably with mortality rate) (Amburgey et al., 1993; Haveman, 1992). However, different types of organizational changes do not have the same effect on firm performance given each dimension's unique nature; therefore, we cautiously explore the different effect of each dimension on firm performance.

Firm size and level of resource commitment usually refer to a firm's ability to absorb high operating costs (Kumar, 1984). Subsidiaries need sufficient resources to absorb these costs (Hood \& Young, 1979). Prior studies in organizational theory and IB arenas have paid considerable attention to the role of firm size as a constraint (Bronzini, 2007; Hannan \& Freeman, 1984; Miller \& Chen, 1994; Oliva \& Rivera-Batiz, 2002; Xie, 2011). However, less attention has been paid to the effect of post-entry change in size as the adaptation mechanism (i.e., change in the level of resource commitment) on survival. Depending on their strategic orientation to the general environment or strategic priority, firms could enter foreign markets and launch their activities with either a small or a large investment amount.

Unlike the selection view, the adaptation perspective suggests that organizations may attain a greater chance of survival when continuously attempting to adapt to the changing environment of a host country (Barnett \& Bugelman, 1996; Singh et al., 1986). That is, it can be argued that organizations can and do change their size to adapt to the changing environment of the host country. In a study on Korean personal computer manufacturers from 1981 to 1993 , Kim (1995) found that they continued to survive through changes in the number of employees in the domestic market. The preliminary data analysis shows that foreign subsidiaries of Korean textile firms have changed investment amount in different ways over time. That is, some subsidiaries have maintained the same amount of foreign investment throughout their lifetime, some have experienced a minor increase or decrease in investment amount (e.g., from a $\$ 5,000$ investment amount in 1986 to a $\$ 5,010$ amount in 1987), and others have engaged in a major increase or decrease in investment amount. Given that no definite criterion exists, we suggest that more than a 10 percent increase or decrease in investment amount is a major organizational change in size for a subsidiary to adapt to a changing local environment. Thus, we assume that after foreign subsidiaries enter foreign markets with either a small or a large investment amount, they may continuously change investment amount to actively adapt to a changing local environment, thereby reducing mortality rates in a foreign market.

Hypothesis 1: A post-entry ongoing change in the investment amount of a foreign subsidiary will be negatively associated with its mortality rate in the host market.

The choice of ownership structure is the outcome of the strategic preference of the parent company (Chang \& Rosenzweig, 2001) and is determined by unobserved parent company and host country factors (Mani, Antia, \& Rindfleisch, 2007). Mutinelli and Piscitello (1998) acknowledged that the rate of ownership is determined under conditions of uncertainty that flow from unfamiliar factors within the socio-economic environment of a foreign country. MNEs prefer subsidiaries with $100 \%$ ownership structure (i.e., greenfield investment) when attempting to capitalize on their firm-specific advantages (Barkema \& Vermeulen, 1998). The ownership structure decision, whether a binary entry mode (i.e., joint venture versus wholly owned venture) or a continuous rate of ownership, is among the most important corporate strategic decisions for FDIs because it indicates control or governance over, (Killing, 1983) and commitment (Mjöen \& Tallman, 1997) to, a foreign subsidiary. Whereas the binary entry mode decision helps researchers understand the strategic distinction between sole and shared ownership, the alternative method is more useful in capturing minor changes in ownership level (Dhanaraj \& Beamish, 2004). Measurement of changes in ownership level needs to be fine-grained because even a tiny portion of equity implies control and dominance. Accordingly, this delicate measurement helps us understand and measure the adaptive process by capturing and 
comparing even tiny changes in the ownership level at two temporal points. As a specific example, CEOs of Korean textile firms confirmed in their interviews that they slightly changed the level of ownership as a fundamental adaptation mechanism in a changing local environment (Kim, 2014).

Prior studies suggested that the choice of ownership level significantly influences the mortality rate of overseas joint ventures (Dhanaraj \& Beamish, 2004; Killing, 1983). For instance, some researchers suggested that a dominant ownership level contributes to the stability of joint ventures because less conflict occurs among partners (Blodgett, 1992), whereas others emphasized that an equal ownership level leads to both parties' maximum involvement, resulting in less instability (Mjöen \& Tallman, 1997). Regardless of this controversy, the fundamental assumption of these studies implies that the choice of ownership level may determine the mortality rate. The preliminary data analysis also shows that Korean textile firms have changed the level of ownership of their foreign subsidiaries. Some have maintained the same ownership portion during their lifetimes. Some have made a minor increase or decrease (e.g., less than 5\%) in ownership. Some have made a sizable change in their ownership (e.g., more than 5\%, or from partnership to wholly owned venture). Given that no theory-driven criterion exists, we regard a more than $5 \%$ change in ownership as a considerable change in ownership structure that may directly influence subsequent performance. Thus, we are able to use this criterion to track whether post-entry ongoing change occurred in ownership.

This study carefully explores how post-entry ongoing changes in ownership influence the subsequent mortality rate. This study employs the main tenet of the adaptation view and assumes that foreign subsidiaries have continuously implemented a considerable change in ownership to survive the transforming environment of a host country.

Hypothesis 2: A post-entry ongoing change in the ownership of a foreign subsidiary will be negatively associated with its mortality rate in the host market.

Researchers in IB and the strategy literature have explored and qualified the relationship between the scope of firm activities (i.e., product areas) and firm performance (Hoskisson, Eden, \& Lau, 2000; Montgomery, 1982; Rumelt, 1974). Nevertheless, IB researchers have disregarded the effect of a post-entry product change on performance. Changes in product areas are core changes because they transform the relationship with local customers and suppliers, strategic resources and capabilities, and market position in the host country. For example, from a study of 160 U.S. radio markets, Greve (1999) found that low-performing organizations in the market could successfully improve their market shares through changes in target products.

Organizations use changes in product areas as important elements of organizational change and strategic determinants of performance differences (Singh et al., 1986). The preliminary data analysis shows that foreign subsidiaries of Korean textile firms have used changes in three core product areas (i.e., clothing, industrial textiles, and living goods) as a post-entry strategy to adjust to a transforming local environment. Some firms have done business in a specific product area(s), whereas others have added new products from other product areas or deleted products from current area(s). Thus, we are able to track whether considerable changes occurred in a foreign subsidiary's product areas during the observation period.

Based on the width of their business areas, organizations are likely to adopt an early strategic orientation to meet their general environment (Brittain, 1989). Organizational changes in product areas may occur because of changes in the environmental variability and resource availability within the environment. For example, in an unfavorable environment, organizations attempt to respond to environmental changes by reducing the width of product areas, whereas they expand their product areas in a favorable environment (Kim, 1995). Accordingly, foreign subsidiaries may reduce their mortality rates by altering the width of their product areas.

Hypothesis 3: A post-entry ongoing change in the product areas of a foreign subsidiary will be negatively associated with its mortality rate in the host market. 


\section{DATA AND METHODOLOGY}

\section{Sample}

The sample consists of 2,582 foreign subsidiaries by year cases established by 842 Korean textile firms across 44 host countries between 1986 and 1995. The sample offers a proper context because it includes both winners and losers to identify the effect of organizational changes on foreign subsidiaries' survival during the observation period (Barnett \& Burgelman, 1996). This study was left censored in 1986 because few FDIs existed before 1986 (Allison, 1984). This study was right censored in 1995 because we focus on the early period during which the literature focusing on FDIs by developing countries did provide little empirical evidence (Canabal \& White III, 2008).

\section{Measures}

\section{Dependent Variable}

\section{Mortality Rate of Foreign Subsidiary}

The possibility of a subsidiary's exit from the foreign market at a given time was employed as a dependent variable. The exit possibility measures the qualitative change between two temporal periods. We can consider closure, divestiture, and liquidation a subsidiary's exit from host countries. However, this study uses the overall exit possibility because the data do not provide a classification rule or code to distinguish type of exit. Like previous studies, this study measures the exit possibility at the end of a given year (Chang, 1995; Hennart, Kim, \& Zeng, 1998). At the end of a year, exit occurrence is coded 1 , and 0 otherwise.

\section{Independent Variables}

\section{Change in Investment Amount}

Previous studies measured the size of a firm in various ways such as sales volume (Agarwal \& Ramaswami, 1992), total assets (Kogut \& Singh, 1988), and number of employees (Norburn \& Birley, 1988). However, this study employs the investment amount in a given year as a proxy for subsidiary size in that the sample has a consistent record of investment amount. Because no theory-driven criterion exists to determine significant change in investment amount, this study considers a more than 10 percent increase or decrease in investment amount as a considerable change in subsidiary size. Accordingly, such more than a 10 percent decrease or increase in the investment amount during the observation period is coded as 1 , and 0 otherwise.

\section{Change in Ownership}

Because the data provide information on the parent company's ownership in its subsidiary, this study is able to track changes in the ownership of a parent company of its foreign subsidiary. Similar to changes in investment amount, ongoing changes in ownership are viewed as part of the adaptation process. Because the data do not provide the reason for a change in ownership, this study considers only the overall change in ownership of a subsidiary between two years. Given that no theoretical criterion exists to determine significant change in ownership, this study regards more than a 5\% increase or decrease in ownership as a considerable change in ownership structure. Such more than a $5 \%$ increase or decrease in ownership is coded as 1 , and 0 otherwise. This study tracked whether post-entry ongoing changes in ownership occurred.

\section{Change in Product Areas}

The Korean Standard Industry Code (KSIC) classifies Korean textile product areas from fiber to clothing based on two- and three-digit codes. This study employs the three-digit KSIC codes (Montgomery \& Wernerfelt, 1988) to identify changes by a foreign subsidiary in the three core areas of clothing, industrial textiles, and living goods. Either 
the addition or the deletion of products in the three core areas is viewed as a considerable change in product area. Change in three areas is coded as 1 , and 0 otherwise.

\section{Control Variables}

This study controls for subsidiary, parent company, and local environment variables because they may affect the mortality rate of foreign subsidiaries. First, this study controls for a subsidiary's size and age because small and new organizations have a so-called liability of smallness (Aldrich \& Auster, 1986; Hannan \& Freeman, 1984) and liability of newness (Singh et al., 1986). Small firms tend to face a systematic high liability of mortality rate. This study regards the investment amount for a foreign subsidiary in a given year as its size, and its age is measured as the number of its operating years (Chang, 1995).

Second, this study controls for the parent company's FDI experience and the degree of commitment to its subsidiary. Subsidiaries are likely to benefit from their parents' FDI experience (Chang, 1995; Zeng, Shenkar, Song, \& Lee, 2013). The prior FDI experience of the parent company in a given year is coded as 1 , and 0 otherwise.This study controls for the effect of the wholly owned subsidiary, given MNEs tend to enhance commitment to their foreign subsidiaries through a wholly owned subsidiary (Kogut \& Singh, 1988; Li, 1995). In addition, given FDI decisions are largely based on the low factor costs such as wages in host countries (Tsang \& Yip, 2007), this study assumes that increasing wages in the domestic market may facilitate parent companies' FDI activities in a host country with lower labor costs. Accordingly, this study controls for changes in average monthly wages in the three main sectors (i.e., clothing, industrial textiles, and living goods) of the Korean textile industry.

Third, a host country's market size and political risks are controlled (Quer, Claver, \& Rienda, 2012), given that FDI decisions largely rely on local economic and institutional environments. This study measures market size as the logtransformed real GDP in U.S. dollars and political risk as POLCON V (Henisz, 2002). POLCON V designates the likelihood of change in the policy regime, where 0 indicates "most hazardous" and 1 indicates "most constrained."

\section{Analytical Method}

This study primarily investigates how a foreign subsidiary's mortality rate (i.e., exit rate) is influenced by organizational changes in the core areas of a foreign subsidiary. To test the possibility of a subsidiary's exit from the foreign market at a given time, this study employs the logarithm of the hazard rate (Allison, 1984; Li, 1995). A main tenet of the hazard rate model is the risk set, defined as the set of firms at risk of a given event at a given point in time. Hence, the hazard rate is defined as the probability that an organization exposed to a particular risk will face that risk at a particular time. A specific hazard model is:

$h(t)=\lim _{\Delta t \rightarrow 0}\left(\frac{\operatorname{Pr}[\operatorname{exit}(t, t+\Delta t) \mid \text { alive at } t}{\Delta t}\right)$

where $\operatorname{Pr}[$.$] represents the probability that a foreign firm will exit between time t$ and $t+\Delta t$, and $h(t)$ represents the instantaneous exit rate of a foreign subsidiary at age $t$.

\section{RESULTS}

Table 1 shows the mean and standard deviation of variables, and displays the correlations between variables. Table 1 indicates the low correlations between most of the variables.

Model 3 in Table 2 tested the relationship between post-entry organizational changes and mortality rate, whereas Models 1 and 2 included only the control variables at subsidiary, parent, and local environment levels that might be linked to mortality rate. In addition to the improvement in the log likelihood across all models, the improvement in the chi-square is significant at the $1 \%$ confidence level. The pseudo R-square statistic in Model 3 is $10.80 \%$. Therefore, arguably, the covariates in Model 3 are non-trivial for the explanation of a subsidiary's mortality. 
Regarding the control variables, an organization's age is positively related to the mortality rate only in Model 1 at a weakly significant level, suggesting that as a subsidiary's age increases, its mortality rate increases. Concerning the parent companies' commitment to FDI, the results show that a wholly owned subsidiary has a negative relationship with mortality rate at a weakly significant level $(\mathrm{p}<0.1)$, indicating that a wholly owned subsidiary is likely to have a lower mortality rate than a joint venture; that is, the higher the parent company's commitment to its foreign subsidiaries, the lower its subsidiary's mortality rate. The results reveal that increases in the monthly average wage in the Korean textile industry are negatively related to the mortality rate of a foreign subsidiary at a strong significance level $(\mathrm{p}<0.01)$ across all models, indicating that when a parent company faces higher labor costs in the domestic market, it tends to increase its commitment to its foreign subsidiary in a host country with lower labor costs. The results also reveal that firms doing business in China are less likely to fail, partially because of the favorable diplomatic relationship between Korea and China that was officially established in 1992. Apparently, firms doing business in China could take advantage of favorable diplomatic partnerships. However, the results show that the political and economic factors of host countries have little influence on the mortality rates of Korean textile subsidiaries.

Hypothesis 1 predicted that post-entry ongoing changes in the investment amount of a foreign subsidiary have a negative relationship with the subsidiary's mortality rate. The results in Model 3 strongly support Hypothesis 1. Hypotheses 2 and 3 predicted that post-entry ongoing changes in ownership and product areas of a subsidiary are negatively associated with the subsidiary's mortality rate. The results in Model 3 support Hypothesis 3 but not Hypothesis 2. Generally, to a large extent, the results support the adaptation perspective's argument that post-entry ongoing organizational changes in the core areas lead to a lower mortality rate (Amburgey et al., 1993; Baum \& Oliver, 1991; Delacroix \& Swaminathan, 1991; Haveman, 1992) and, thus, longer organizational survival (Levinthal, 1991; Levitt \& March, 1988).

Table 1. Means, Standard Deviations (s.d.), and Correlations

\begin{tabular}{|c|c|c|c|c|c|c|c|c|}
\hline & Variable & Mean & s.d. & 1 & 2 & 3 & 4 & 5 \\
\hline 1 & Mortality & .0348 & .1834 & & & & & \\
\hline 2 & SSize (USD) & 12.697 & 1.273 & -.0024 & & & & \\
\hline 3 & SAge & 2.8262 & 1.9452 & -.0038 & $.0542^{*}$ & & & \\
\hline 4 & FDI Exp. & .1857 & .3889 & -.0232 & $.2418^{*}$ & $.0701^{*}$ & & \\
\hline 5 & Wholly & .5241 & .4995 & -.0254 & $.0679^{*}$ & $.0572^{*}$ & $.0810^{*}$ & \\
\hline 6 & Wage (KWN) & 651446 & 161524 & $-.1344^{*}$ & -.0261 & $.2079^{*}$ & -.0335 & $-.0468^{*}$ \\
\hline 7 & POLCON V & .2540 & .3191 & $.0480^{*}$ & $.0468^{*}$ & $.1943^{*}$ & $.1278^{*}$ & $.2086^{*}$ \\
\hline 8 & GDP & 739.28 & 1643.7 & .0350 & $.0524^{*}$ & $.0687^{*}$ & $.0778^{*}$ & $.0963^{*}$ \\
\hline 9 & Ownership & .0178 & .1322 & .0050 & $.0434^{*}$ & $.0394^{*}$ & -.0066 & $-.0458^{*}$ \\
\hline 10 & Investment & .4174 & .4932 & $-.0788^{*}$ & $.1308^{*}$ & $.2070^{*}$ & $.1042^{*}$ & $.1368^{*}$ \\
\hline 11 & Product & .0515 & .2211 & -.0169 & $-.0188^{*}$ & $.1527^{*}$ & $-.0897^{*}$ & .0341 \\
\hline & Variable & Mean & s.d. & 6 & 7 & 8 & 9 & 10 \\
\hline 7 & POLCON V & .2540 & .3191 & $-.1879^{*}$ & & & & \\
\hline 8 & GDP & 739.28 & 1643.7 & $-.0716^{*}$ & $.4569^{*}$ & & & \\
\hline 9 & Ownership & .0178 & .1322 & .0182 & .0095 & .0022 & & \\
\hline 10 & Investment & .4174 & .4932 & $-.1181^{*}$ & .0137 & -.0384 & $.0680^{*}$ & \\
\hline 11 & Product & .0515 & .2211 & $-.1397^{*}$ & .0225 & $.0635^{*}$ & $.0701^{*}$ & $.1530^{*}$ \\
\hline
\end{tabular}

Notes: SSize: Subsidiary's size in log-transformed investment amount; SAge: Subsidiary's age; FDI Exp.: Parent company's experience in FDI; Wholly: Wholly owned FDI; Wage: Textile industry average monthly wage in Korea (where KWN indicates the Korean currency unit); POLCON V: Henisz's political constraints scores of host country; Ownership, Investment, Product indicate change in ownership, change in investment amount, and change in product areas, respectively. ${ }^{*} \mathrm{p}<0.05$ 
Table 2. Results of Hazard Rate Model

\begin{tabular}{|c|c|c|c|c|}
\hline & & Model 1 & Model 2 & Model 3 \\
\hline \multirow{3}{*}{$\begin{array}{l}\text { Control: } \\
\text { Subsidiary } \\
\text { characteristics }\end{array}$} & Constant & $\begin{array}{l}22.2988 \\
(2.9887)\end{array}$ & $\begin{array}{l}18.6339 \\
(3.6646)\end{array}$ & $\begin{array}{l}23.3374 \\
(4.2030)\end{array}$ \\
\hline & Subsidiary Size (USD) & $\begin{array}{c}.0628 \\
(.0894)\end{array}$ & $\begin{array}{l}.0256 \\
(.0923)\end{array}$ & $\begin{array}{l}.1050 \\
(.0980)\end{array}$ \\
\hline & Subsidiary Age & $\begin{array}{c}.0977 \\
(.0564)^{\dagger}\end{array}$ & $\begin{array}{c}.0109 \\
(.0664)\end{array}$ & $\begin{array}{c}.0816 \\
(.0699) \\
\end{array}$ \\
\hline \multirow{3}{*}{$\begin{array}{l}\text { Control: } \\
\text { Parent company } \\
\text { characteristics }\end{array}$} & Parent Company's FDI Experience & $\begin{array}{c}-.3827 \\
(.3151)\end{array}$ & $\begin{array}{l}-.4363 \\
(.3138)\end{array}$ & $\begin{array}{l}-.3981 \\
(.3142)\end{array}$ \\
\hline & Wholly Owned FDI & $\begin{array}{l}-.3751 \\
(2160)^{\dagger}\end{array}$ & $\begin{array}{l}-.3593 \\
(.2351)\end{array}$ & $\begin{array}{l}-.1889 \\
(.2537)\end{array}$ \\
\hline & Wage $(\mathrm{KWN})$ & $\begin{array}{l}-1.9370 \\
\left(.2281^{* *}\right.\end{array}$ & $\begin{array}{l}-1.6301 \\
\left(.2859^{* *}\right.\end{array}$ & $\begin{array}{l}-1.9687 \\
\left(.3253^{* * *}\right.\end{array}$ \\
\hline \multirow{3}{*}{$\begin{array}{l}\text { Control: } \\
\text { Host country factors }\end{array}$} & POLCON V & & $\begin{array}{l}-.0699 \\
.4833)\end{array}$ & $\begin{array}{l}-.3278 \\
(.5195)\end{array}$ \\
\hline & GDP & & $\begin{array}{c}.0007 \\
(.0007)\end{array}$ & $\begin{array}{l}.0007 \\
(.0007)\end{array}$ \\
\hline & China & & $\begin{array}{c}-.7161 \\
(.4075)^{\dagger}\end{array}$ & $\begin{array}{l}-.8230 \\
(.4193)^{*}\end{array}$ \\
\hline $\mathrm{H} 1$ & Change in Investment Amount & & & $\begin{array}{l}-1.3086 \\
(.2881)^{* *}\end{array}$ \\
\hline $\mathrm{H} 2$ & Change in Ownership & & & $\begin{array}{c}.8383 \\
(.7434)\end{array}$ \\
\hline \multirow[t]{5}{*}{$\mathrm{H} 3$} & Change in Product Areas & & & $\begin{array}{l}-1.2778 \\
\left(.4900^{* * *}\right.\end{array}$ \\
\hline & Log Likelihood & -385.3005 & -358.0732 & -342.3893 \\
\hline & Model Chi-square & $74.68^{* *}$ & $77.74^{* *}$ & $85.96^{* *}$ \\
\hline & Pseudo R-square & .0554 & .0671 & .1080 \\
\hline & No. of Obs. & 2,698 & 2,582 & 2,582 \\
\hline
\end{tabular}

Note: (Dep. Variable: Mortality Rate), ${ }^{* *} \mathrm{p}<0.01,{ }^{*} \mathrm{p}<0.05,{ }^{\dagger} \mathrm{p}<0.1$

\section{DISCUSSION AND IMPLICATIONS}

By applying two organizational theories to understand FDIs established by Korean textile firms between 1986 and 1995, a period during which the IB literature provides insufficient statistical empirical evidence about the post-entry organizational change-performance relationship, this study examined how post-entry ongoing organizational changes in the core areas of foreign subsidiaries of Korean textile firms are related to their mortality rates (i.e., exit rates) in host countries. Paying attention to the relationship between post-entry organizational changes and subsequent mortality rates may contribute to our understanding of the primary question: What are the consequences of organizational change? (Barnett \& Carroll, 1995). The findings show that changes in the core dimensions of foreign subsidiaries definitely contribute to reducing their mortality rates in host countries. However, this study carefully confirms that not all organizational changes have an identical effect on mortality rates.

Given that organizational changes occur in diverse core areas, this study specified and qualified the different effect of organizational changes in the three core areas of investment amount, ownership, and products of a foreign subsidiary on its mortality rate. We found that although post-entry ongoing changes in investment amount and product areas significantly contribute to reducing a subsidiary's mortality rate, changes in ownership do not influence the mortality rate. This finding may result from a subsidiary's ability to quickly respond to a changing local environment through post-entry modifications in investment amount and product areas. That is, parent companies can rapidly change the level of resource commitment to their subsidiaries or product areas in response to a host country's transforming environment. In contrast, changing the ownership structure is more complex given the management and control problems between partners. Moreover, additional expenses arising from coordination problems are unavoidable. Changes in organizational structure are indirectly related to the basic work activities of an organization and more directly related to its management (Tsoukas, 1996). Therefore, organizational change in ownership might be indirectly 
rather than directly related to the subsequent mortality rate; future research may be enriched by demonstrating the indirect relationship.

To understand the pure effect of organizational changes in investment amount and product areas, this study held all other variables constant in Model 3 and calculated the marginal effect of each factor. A single increase in the subsidiary's investment amount is expected to reduce its mortality rate by $27.02 \%$ (i.e., $\mathrm{e}^{-1.3086}$ ) compared with a counterpart whose investment amount remains unchanged. Likewise, a single increase in a subsidiary's product areas is estimated to reduce its mortality rate by $27.87 \%$ (i.e., $\mathrm{e}^{-1.2778}$ ) compared with an opposite subsidiary whose product areas remain unchanged.

This study controlled for other confounding interpretations. The selection view contends that, as an organization's age and size increase, its mortality rate decreases because structural inertia plays a critical role in increasing its reliability and accountability. This study contradicts this view, although at a weakly significant level, indicating that a subsidiary's mortality rate increases as its age increases. Moreover, Kim (2014) found that most foreign subsidiaries of Korean textile firms experience a five-year honeymoon period, the so-called liability of adolescence, suggesting that the risk is high at the end of the five-year honeymoon period. The results also reveal that the effect of size is not statistically significant. These results imply that structural inertia does not impede organizational change and adaptation (Aldrich \& Auster, 1986). Because foreign subsidiaries of the Korean textile firms are small and have little structural inertia, they are able to quickly respond to changing local environments. Apparently, firm size does not matter, at least in the Korean textile industry.

This study controlled for a parent company's commitment to its foreign subsidiary and found the expected result. A wholly owned subsidiary was negatively related to the mortality rate of a subsidiary at a weakly significant level. When a parent company adopts a wholly owned entry mode, its commitment to its subsidiary appears stronger, perhaps because a joint venture - whether a majority- or minority-owned subsidiary - is intricately intertwined with two or more partners, providing less autonomy and reducing the flexibility of its response to changing environments. Furthermore, the results provide strong evidence that as wages in the home country increase, a subsidiary's mortality rate in a foreign market decreases. This result might suggest that changes in the economic environment in the home country generate redundant resources and enable the parent company to make a stronger commitment to its foreign subsidiary. In other words, under the unfavorable economic environment in the home country, investments in foreign subsidiaries take strategic priority for the parent company. However, this study does not support the view that a parent company's prior experience with FDI reduces the mortality rate of its subsidiary, possibly because Korean textile firms are labor intensive and, therefore, do not rely significantly on previous experience. Instead, finding a host country with lower labor costs may be a priority in FDI strategy.

This study puts forward some theoretical and practical implications. With respect to theoretical implications, this study first attempted to extend the study of FDI by applying conventional organizational theories to the FDI context and exploring FDIs made by labor-intensive Korean textile firms during the early period, given that prior studies have largely relied on FDIs established by MNEs in developed countries. The findings show that the two organizational theories, which are less utilized in the IB literature, are similarly useful for understanding the adaptation process of foreign subsidiaries. Specifically, we provided evidence for the adaptation view that post-entry ongoing organizational changes in the core areas of a foreign subsidiary are negatively related to its mortality rate. Second, this study provides fresh evidence for the argument by Ghemawat (1991) that the concept of commitment at the individual level may be applied at the organizational level. The findings show that the higher the parent company's commitment to its foreign subsidiary, the lower its foreign subsidiary's mortality rate.

This study also has several practical implications. First, given that organizational changes do not uniformly influence the mortality rate, firms should pay more attention to the dominantly influencing factors to reduce the mortality rate of their subsidiaries in host countries. Second, this study demonstrated that foreign subsidiaries of Korean textile firms face the liability of adolescence (see Figure 1), not the liability of newness. During this period, firms may attempt to make organizational changes to overcome this liability or may consider an exit strategy depending on their strategic priority. 
In addition to the primary questions, we attempted to fill another gap in the IB literature. First, Canabal and White III (2008) found in their meta-analysis that the apparent limited access to or lack of data during the early period would not provide a complete understanding of FDI during the early years. Second, FDI research by large MNEs in developed countries - the so-called "Triad of Developed Nations" such as the United States, Western Europe, and Japan - was dominantly studied during the early period, but little attention was paid to outward FDIs made by MNEs in developing nations during the same period. Our data provide statistical evidence for the early period between the mid-1980s and the mid-1990s, a relatively unexplored period. In addition, our findings suggest that the two theoretical perspectives on organizational change, which have focused on the parent company and population level, may be also applied to explain the post-entry adaptive process of subsidiaries.

This study has some limitations. First, the sample was right censored in 1995 because this study focused on the early period during which few empirical studies to examine FDIs executed by MNEs in developing countries were provided. Accordingly, the results may not be generalized to explain FDIs established by the firms that started FDIs after 1993. Nonetheless, this study still can contribute to the IB literature by investigating the FDI activities of Korean firms in the period on which few empirical studies have focused. Second, this study focused on organizational change in core areas of foreign subsidiaries; however, subsidiaries are also able to decrease their mortality rate by strategically changing peripheral areas (e.g., change in specific operational tactics). Third, although acknowledging that the direction of organizational change matters for the mortality rate because scaling up investments is a signal of good performance while scaling down may be a signal of a precursor to exit, this study did not test the effect of a positive or negative directional change in the core areas. Further studies need to carefully investigate the directional effect in order to provide additional detail implications.

\section{CONCLUSION}

This study investigated the relationship between post-entry ongoing organizational changes in the core areas of foreign subsidiaries and subsequent performance. The findings support the adaptation view that post-entry ongoing organizational changes of overseas subsidiaries reduce their mortality rate in host countries. In addition, the findings cautiously acknowledge that the effects of post-entry organizational changes on mortality rates are not identical. This study added a theoretical contribution to the IB literature in that it employs conventional organizational theories to understand FDIs.

\section{ACKNOWLEDGEMENTS}

This work was supported by the Ministry of Education of the Republic of Korea and the National Research Foundation of Korea (NRF-2016S1A5A8019974).

\section{AUTHOR BIOGRAPHY}

Kyungho Kim, DBA, is an associate professor at School of Business, Ajou University. He received his DBA from Boston University. His research areas include corporate strategy, international business strategy, corporate social responsibility, and environmental sustainability. Please direct all correspondence to Kyungho Kim (kyunghokim@ajou.ac.kr).

\section{REFERENCES}

Aldrich, H, E., \& Auster, E. R. (1986). Even dwarfs started small: Liabilities of age and size and their strategic implications. Research in Organizational Behavior, 8, 165-198.

Allison, P. D. (1984). Event history analysis: Regression for longitudinal event data. Newbury Park: Sage Publications.

Amburgey, T., Kelly, D., \& Barnett, W. (1993). The dynamics of organizational change and Failure. Administrative Science Quarterly, 38(1): 51-73.

Agarwal, S., \& Ramaswami, S. N. (1992). Choice of Foreign Market Entry Mode: Impact of ownership, location and internalization factors. Journal of International Business Studies, 23(1), 1-27.

Barkema, H.G., \& Vermeulen, F. (1998). International expansion through start-up or acquisition: A learning perspective. Academy of Management Journal, 41(1), 7-26.

Barnett, W. P., \& Burgelman, R. A. (1996). Evolutionary perspectives on strategy. Strategic Management Journal, 17(1), 5-19. 
Barnett, W.P., \& Carroll, G.R. (1995). Modeling internal organizational change. Annual Review of Sociology, 21, $217-236$.

Barnett, W.P., \& Freeman, J.F. (1997). Too much of a good thing? Product proliferation and organizational failure. Research Paper No. 1425, Graduate School of Business, Stanford University.

Baum, J. A., \& Oliver, C. (1991). Institutional linkages and organizational mortality. Administrative Science Quarterly, 36(2), 187-218.

Blodgett, L.L. (1992). Factors in the instability of international joint ventures: an event history analysis. Strategic Management Journal, 13(6), 475-481.

Brittain, J. W. (1989). Environmental change and organizational selection in semiconductor manufacturing, Ph. D. Dissertation, University of California, Berkely.

Bronzini, R. (2007). FDI inflows, agglomeration and host country firms' size: evidence from Italy. Regional Studies, 41(7), 963978.

Brown, S.L., \& Eisenhardt, K.M. (1997). The art of continuous change: Linking complexity theory and time-paced evolution in relentlessly shifting organizations. Administrative Science Quarterly, 42(1), 1-34.

Canabal, A., \& White III, G.O. (2008). Entry mode research: Past and future. International Business Review, 17(3), $267-284$.

Chang, S.J. (1995). International expansion strategy of Japanese firms: Capability building through sequential entry. Academy of Management Journal, 38(2), 383-407.

Chang, S.J., \& Rosenzweig, P. M. (2001). The choice of entry mode in sequential foreign direct investment. Strategic Management Journal, 22(8), 747-776.

Dhanaraj, C., \& Beamish, P.W. (2004). Effect of equity ownership on the survival international joint ventures. Strategic Management Journal, 25(3), 295-305.

Delacroix, J., \& Swaminathan, A. (1991). Cosmetic, speculative, and adaptive change in the Wine industry: A longitudinal study. Administrative Science Quarterly, 36(4), 631-661.

Freeman, J., \& Hannan, M. T. (1983). Niche width and the dynamics of organizational Populations. American Journal of Sociology, 95(1), 425-439.

Freeman, J., Carroll, G. R., \& Hannan, M. T. (1983). The liability of newness: Age dependence in organizational death rates. American Sociological Review, 48(5), 692-710.

Ghemawat, P. (1991) Commitment: The dynamic of strategy, NY: Free Press.

Greve, H.R. (1999). The effect of core change on performance: Inertia and regression toward the mean. Administrative Science Quarterly, 44(3), 590-614.

Hannan, M. T., \& Freeman, J. (1984). Structural inertia and organizational change. American Sociological Review, 49(2), 149164.

Haveman, H. A. (1992). Between a rock and a hard place: Organizational change and performance under conditions of fundamental environmental transformation. Administrative Science Quarterly, 37(1), 48-75.

Henisz, W.J. (2002). The institutional environment for infrastructure investment. Industrial and Corporate Change, 11(2), 355389.

Hennart, J.F., Kim, D., \& Zeng, M. (1998). The impact of joint venture status on the longevity of Japanese stakes in U.S. manufacturing affiliates. Organization Science, 9(3), 382-395.

Hoskisson, R.E., Eden, L., Lau, C.M., \& Wright, M. (2000). Strategy in emerging economies. Academy of Management Journal, 43(3), 249-267.

Hood, N., \& Young, S. (1979). The economics of multinational enterprise. London: Longman Group Ltd.

Killing, P.J. (1983). Strategies for Joint Venture Success. Praeger: New York.

Kim, J. (1995). An organizational ecology approach to organizational strategy change and mortality in Korean Personal Computer Manufactures, Ph. D. Dissertation, The Business School of Seoul National University.

Kim, K.H. (2014). Post-entry incremental change in foreign investment and subsidiaries' survival in host countries: Moderating effect of government corruption. Journal of International Trade \& Commerce, 10(2), 133-167.

Kogut, B., \& Singh, H. (1988). The effect of national culture on the choice of entry mode. Journal of International Business Studies, 19(3), 411-432.

Kok, R., \& Ersoy, B.A. (2009). Analyses of FDI determinants in developing countries. International Journal of Social Economics, 36(1/2), 105-123.

Kumar, M.S. (1984). Growth, acquisition, and investment; An analysis of the growth of industrial firms and their overseas activities. Cambridge: Cambridge University Press.

Levinthal, D. A. (1991). Organizational adaptation and environmental selection-interrelated processes of change. Organization Science, 2(1), 140-145.

Levitt, B., \& March, J. G. (1988). Organizational learning. Annual Review of Sociology, 14, 319-340.

Li, J. (1995). Foreign entry and survival: Effects of strategic choices on performance in international markets. Strategic Management Journal, 16(5), 333-351.

Mani, S., Antia, K.D., \& Rindfleisch, A. (2007). Entry mode and equity level: A multilevel examination of foreign direct investment ownership structure. Strategic Management Journal, 28(8), 857-866.

March, J. G., \& Simon, H. A. (1958). Organizations, NY: Willey.

Miles, R.H. (1982). Coffin nails and corporate strategies, Englewood Cliffs, NJ: Prentice-Hall. 
Miller, D., \& Chen, M. (1994). Sources and consequences of competitive inertia: A study of the U.S. airline industry. Administrative Science Quarterly, 39(1), 1-23.

Mjöen, H., \& Tallman, S. (1997). Control and performance in international joint ventures. Organization Science, 8(3), $257-274$.

Montgomery, C. A. (1982). The measurement of firm diversification: Some new empirical Evidence. Academy of Management Journal, 25(2), 299-307.

Montgomery, C.A., \& Wernerfelt, B. (1988). Diversification, Ricardian rents, and Tobin's q. RAND Journal of Economics, 19(4), 623-632.

Mutinelli, M., \& Piscitello, L. (1998). The influence of firm's size and international experience on the ownership structure of Italian FDI in manufacturing. Small Business Economics, 11(1), 43-56

Norburn, D., \& Birley, S. (1988). The top management team and corporate performance. Strategic Management Journal, 9(3), 225-37.

Oliva, M.A., \& Rivera-Batiz, L.A. (2002). Multinationals, Technology Networks and International Takeovers, Mimeograph: McGill University, Montreal.

Pettigrew, A.M., Woodman, R.W., \& Cameron, K.S. (2001). Studying organizational change and development: Challenges for future research. Academy of Management Journal, 44(4), 697-713

Quer, D., Claver, E. \& Rienda, L. (2012). Political risk, cultural distance, and outward foreign direct investment: Empirical evidence from large Chinese firms. Asia Pacific Journal of Management, 29, 1089-1104.

Rumelt, R. P. (1974). Strategy, structure and economic performance, Cambridge, MA: Harvard University Press.

Sharma, V.M., \& Erramilli, M.K. (2004). Resource-based explanation of entry mode choice. Journal of Marketing Theory and Practice, 12(1), 1-18.

Singh, J. V., \& Lumsden, C. J. (1990). Theory and research in organizational ecology. Annual Review of Sociology, 16, 161-195.

Singh, J. V., House, R. J., \& Tucker, D. J. (1986). Organizational change and organizational Mortality. Administrative Science Quarterly, 31(4), 587-611.

Stinchcombe, A. L. (1965). Social Structure and Organizations', In James G. March (Eds.), Handbook of Organizations, $153-193$. Chicago: Rand McNally.

Tsang, E.W.K., \& Yip, P.S.L. (2007) Economic distance and the survival of foreign direct investments. Academy of Management Journal, 50(5), 1156-1168.

Tsoukas, H. (1996). The firm as a distributed knowledge system: A constructionist approach. Strategic Management Journal, 17(1): 11-26.

Tsoukas, H., \& Chia, R. (2002). On organizational becoming: Rethinking organizational change. Organization Science, 13(5), 567-582.

Zeng, Y., Shenkar, O., Song, S., \& Lee, S.-H. (2013). FDI experience location and subsidiary mortality differences in national culture and the expansion of Korean MNEs. Management International Review, 53(3), 477-509.

Xie, Q. (2011). State ownership, firm size, and Chinese firms' entry mode choice. Asia Pacific Journal of Management, 30(1), March, doi:10.1007/s10490-010-9222-8. 